\title{
WATER MITES ON ODONATES
}

This past June (2011), we were visiting family in Loon Lake, SK (near Meadow Lake). While playing in the lake, our sons and their cousins were on a dragonfly rescue mission and fished all floating odonates out of the water. One large dragonfly clung to a stick, which the kids gently placed on the beach. Having just received a brand new camera for my birthday several weeks prior, I was eager to try out my macro lens on the immobilized dragonfly. I got down on my belly and started shooting ... closer, closer, clooooser.... Eventually, my lens was practically touching the dragonfly's eyes. Zooming in, I noticed tiny red mites crawling all over the insect (see inside back cover, top, panel A). They resembled the little red mites that I used to watch while perched on my grandmother's sandstone wall in Germany, but as far as I know, those mites were strictly terrestrial. So I was a bit confused as to why a dragonfly that had recently been taken out of water would have mites crawling on it. A quick search on the Internet suggested that these mites likely belong to the group Hydracarina (also referred to as Hydrachnidia, Hydrachnida, or Hydrachnellae), which includes over 40 families of water mites (for more on these, see the following University of Alberta page: http://sunsite.ualberta.ca/Projects/ Aquatic Invertebrates/?Page=23). I wouldn't even begin to make an attempt at identification, but perhaps some readers are more familiar with Saskatchewan's aquatic invertebrates? Presumably, the mites hitched a ride after the dragonfly had fallen into the water. While I was photographing the downed dragonfly, several ants approached it and began exploring its head and body (see inside back cover, top, panel $B$; one ant is circled in red); I watched carefully to see whether the ants would prey on the mites, but alas, they did not. For the most part the ants appeared to "ignore" the mites. Nevertheless, it was quite interesting to watch this miniaturized action unfold.

On that same beach, I was also pursuing damselflies with my camera. On several individuals, I noticed aggregates of very small, reddish-brown spheres, which, knowing absolutely naught about odonates, I had simply assumed must be eggs (see inside back cover, top, panels $C$ and $D$ ). Coincidentally, while I was double checking the water mites described above, I came across a website on which had been posted several photos showing both a dragonfly and a damselfly sporting virtually identical "eggs" to those that l'd observed. According to this site (http://taos-telecommunity.org/EPOW/ EPOW-Archive/archive_2011/EPOW110418.htm), the spheres are water mites of the Hydrachnida that are engaging in a process termed 'phoresy,' which essentially means that they are hitchhiking on the damsel. The site further explains that "It]he water mites attach to the dragonfly larva during the dragonfly's aquatic stage in ponds, lakes, and other slow-moving waters. The tiny mites then transfer to the adult dragonfly or damselfly when it exits the water and emerges from its larval casing. Like miniature hobos 'riding the rails,' the mites travel with the dragonfly, eventually detaching from it as it becomes sexually mature and returns to water to breed. At this point, the water mites drop off and begin their life cycle all over again, perhaps in a new location some distance from their native waters."

- Victoria Kjoss, 3426 Clover Place, Regina, SK, S4V 1J1. E-mail: <kjoss@ sasktel.net> 